\title{
A Distance-delivered Teacher Education Program for Rural Culturally and Linguistically Diverse Teacher Candidates
}

\author{
Gayla Lohfink \\ Wichita State University
}

\section{Amanda Morales, Gail Shroyer, Sally Yahnke \& Cecilia Hernandez}

\author{
Kansas State University
}

\begin{abstract}
This article describes a collaborative, distance-delivered, teacher preparation program for rural, culturally and linguistically diverse (CLD) teacher candidates. Multiple institutions partnered with one university in order to diversify the teaching force in the region and meet the needs of CLD students living there. In describing the program's design and implementation phases, a focus on cultural responsiveness to the candidates' needs, their rural settings, and high populations of Latino/a students in the rural areas in which they were trained is presented. Assessment of each implementation phase guided program practice for the participants' training as effective teachers. Relevant discussion indicates that even with responses to the pre-service teachers' academic, social, and financial needs, issues of communication and barriers imposed by distances emerged. Additionally, while collaborative bonds among the partner institutions facilitated the candidates' training as effective teachers, the building of multi-institutional partnerships concurrently with the implementation phases caused participants and implementers stress.
\end{abstract}

Key words: Culturally and linguistically diverse; teacher preparation program; distance education; rural.

The realities of teacher education programs in the $21^{\text {st }}$ century require that prospective teachers know how to effectively teach an increasingly diverse population of children. Unfortunately, the teacher education system has persistently shown an inability to recruit and retain minority teachers who share the same racial, ethnic, and cultural backgrounds of these diverse students (Gay, Dingus, \& Jackson, 2003). With culturally and linguistically diverse (CLD) students now representing approximately $45 \%$ of our public school populations (Noel \& Sable, 2010), recruiting and retaining teachers of color is a critical issue. Thus, more institutions of higher education across the United States are considering that strong relationships and shared beliefs among school-anduniversity-based faculty can transform teacher education programs to positively increase the number of teachers of color who can effectively meet the needs of CLD children (Bernal \& Aragon, 2004).

The purpose of this study is to describe one such collaborative effort among several educational institutions in an attempt to diversify a particular rural region's teachers by designing and delivering a culturally responsive teacher preparation program to rural CLD candidates. Implications drawn from the program and its participants' training as effective, culturally competent educators reflect a critical need for systemic and collaborative change in the educational continuum that more effectively addresses the historic problems faced in teacher recruitment, retention, and preparation (CochranSmith, 2004).

Interesting circumstances occurring in the rural Midwest involve the issues of increased student diversity and teacher recruitment and retention. To explain, similar to national trends, rural areas in the Midwest are experiencing significant growth in Latino/a populations (US Census Bureau, 2008). Too often a Latino/a student's educational landscape is a "rocky terrain" (Valenciana, Weisman, \& Flores, 2006 , p. 82) that may be additionally compounded by a mismatch between his/her Latino/a cultural and historical background and the racial and ethnic makeup of his/her teachers. Rural local educational agencies are confronted with meeting the educational needs of its Latino/a students by employing highly effective teachers - an issue that becomes additionally problematic as remote, rural areas are frequently challenged to recruit and retain any teacher (Achinstein, Ogawa, Sextion, \& Freitas, 2010). As in the current study, geographic location and access to resources serve as major hindrances for local school districts in recruiting and retaining highly qualified teachers (Gutierrez, 2006). 


\section{Contextual Factors}

In rural areas, thus, the problem of recruiting, retaining, and preparing diverse teachers is compounded with the issue of distance. Currently, colleges and universities are exploring an array of methods to facilitate the delivery of instruction in teacher education, particularly to rural areas critically impacted by the teacher shortages (Jung, GaylonKeramidas, Collins, \& Ludlow, 2006). Utilizing community resources via "grow your own" preservice teacher training projects appears to be a viable means for combating such a problem. These rural pre-service teachers bring to the classroom an awareness of the community - an understanding of the cultural, social, and economic elements of rural living - by reflecting connections with the children they are teaching. Flores, Keehn, and Pérez (2002) noted that most grow-your-own programs are collaborative efforts among university teacher preparation programs and local school districts. Additionally, while not well-documented, community colleges can serve as strong academic partners within grow-your-own programs, as they are often easily accessible and more accommodating to nontraditional students' schedules (Shroyer, Yahnke, Bennett, \& Dunn, 2007).

In 2003, one such collaborative effort was initiated by a state university in the Midwest. At the onset of this effort, the university (referred to as Midwestern State) began a multi-institutional collaborative grant project funded by the US Department of Education. The grant focused on K16 teacher improvement with an emphasis on increasing equity and access to diverse students. Additionally, the grant-financed collaboration among and across participating institutions-Midwestern State (both the College of Education and the College of Arts \& Sciences), three community colleges, and three neighboring school districts located in rural areas of the state. Partnership efforts were numerous; however, for the purposes of this study, the researchers focused on the objective of teacher diversification in one rural region. As stated, this grant objective included implementing a distancedelivered elementary education program, responsive to the diverse needs of teacher candidates located in rural areas most impacted by recent demographic changes in CLD student populations.

Diversification required Midwestern State to go off-campus and collaborate with its rural community college partners to design and deliver a two-plus-two teacher preparation program. Pre-service teachers in the program completed their general education coursework (two years) via the community colleges and then completed upper level coursework through various distance-based modalities (two years) at Midwestern State. Delivering such a teacher preparation program was unique given that significant distances existed between these three partner communities and Midwestern State or other four-year universities or colleges in the tri-state area. Access to higher education or professional development of any kind in the region is a persistent challenge for practicing and aspiring teachers alike.

To begin, Midwestern State considered the specific processes, collaboration, and funds required for conducting a distance-delivered program for the teacher education candidates. Department of Education grant funds could be used to cover programmatic costs, and because it was a partnership grant and not a scholarship grant, Midwestern State could partner with a federal Title III scholarship grant, called Project Synergy, to supply the participants for the two-plus-two program as well as the tuition for these participants to complete a baccalaureate degree in elementary education. Project Synergy had already initiated its process of recruiting and retaining bilingual, Latino/as from rural communities in and nearby the locations of the three community colleges involved with the Department of Education grant. These participants, described as Mexican American, non-traditional, English language learners, and first generation college students, had been previously employed as para-educators or in other school-related occupations. The participants ranged in age from 22 to 57 years old, and each showed commitment to returning to his/her partner districts as teachers upon graduation.

\section{Conceptual Framework}

While recent investigations portray an increase in distance teacher preparation programs (Olson \& Werhan, 2005), the development and delivery of such models to CLD pre-service teachers in rural, remote regions of the US appears limited. This need prompted Midwestern State to collaborate with multiple institutions to design and implement its own grow-your-own program. Because a critical program element was cultural responsiveness to the rural CLD participants, the theoretical lens used to frame the design of the program included not only research and pedagogy focused upon developing candidates' effective teaching characteristics and distance learning practices that incorporated such pedagogy, but also cultural relevant pedagogy.

\section{Effective Teaching Characteristics}

Communities of practice. In the 1980s, literature emerged that described characteristics 
of effective teachers, and this research influenced teacher preparation programs variously. In 2005, the Committee on Teacher Education published the results of its investigation of core concepts and strategies that inform teacher preparation practices (Bransford, Darling-Hammond, \& LePage, 2005). A key finding of the committee's work dealt with the effectiveness of program integration of professional teaching practices. For example, teacher education programs that integrated related strategies across courses and field placements reflected evidence of more effective pre-service teachers' behaviors. When teacher candidates are placed within communities of practice, and actually experience authentic classroom situations and student learning, they are able to see connections between pedagogy and effective teaching strategies (Darling-Hammond \& Baratz-Snowden, 2005). To be even more specific, teachers who graduate from teacher preparation programs where real communities of practices are actualized, such as in Professional Development Schools (PDS), appear more knowledgeable and are better prepared to teach (Darling-Hammond, Hammerness, Grossman, Rust, \& Shulman, 2005)

Cultural relevant pedagogy and responsivity for teaching Latino/as. While effective teacher preparation programs must strive to build and maintain strong professional bonds between institutions of higher education and K-12 schools in order to support professional communities of practice, it is equally as important for them to embed cultural sensitivity within all aspects of their professional communities (Flores, Clark, Claeys, \& Villarreal, 2007). Preparation of effective pre-service teachers requires knowledge, understanding, and use of pedagogy situated in cultural responsivity - a theoretical construct that highlights the role of social mediation in learning and the situated nature of knowledge (Vygotsky, 1986). Teachers who build upon their students' prior knowledge by connecting not only school experiences, but also experiences from their homes, families, and communities impact learning positively (Rueda, Monzó, \& Higareda, 2004). When considering these background experiences, Ladson-Billings (1995) and others (Gay, 2002; Portes, 2008) argued that CLD students, in particular, learn best through instructional approaches that take into account their languages and cultural practices. Effective teachers facilitate students' engagement in learning of concepts by building upon these existing "funds of knowledge" (Moll, Amanti, Neff, \& Gonzalez, 1992, p. 133). Importantly then, in order to produce educators who are equipped to teach in culturally relevant ways, teacher preparation programs must not only explicitly provide such content, but also directly model its practices within their candidates' communities of practice. To explain, Rueda et al. (2004) concluded Latino/a paraeducators" inconsistent "use of their own funds of knowledge to mediate instruction for their students" (p. 70) reflected a lack of understanding of the important link between culture and learning. Research indicates that teachers who do contextualize their students' learning by connecting their prior knowledge to new learning in meaningful ways impact student achievement positively (LadsonBillings; 1995; Villegas \& Lucas, 2007). Helping pre-service teachers become cognizant of culturally relevant strategies or "sociocultural scaffolding practices" (Rueda et al., 2004, p. 83) within their communities of practice is critical to their development of effective teaching characteristics.

\section{Issues in Distance-based Teacher Education.}

Traditional approaches to teacher development may interfere then with a teacher candidate's understanding of effective teacher pedagogy. Reynolds, Treahy, Chao, \& Barab (2001) offered that a lack of learning-as-a-part-of-community experience, such as that observed in Professional Development School settings, limits teachers' engagement in self-reflective practice and conversation with others. While online learning environments supportive of an alternative sense of community are becoming more prevalent in teacher education (Knapczyk, Chapman, Rodes, \& Chung, 2001; Skylar et al., 2005), much of the published work reflecting colleges and universities' use of technology media and instructional methods in their distance coursework relates specifically to preparing special education teachers to teach in rural communities (Jung et al., 2006). Few models of teacher preparation programs for undergraduate preservice teachers were found to relate specifically to the rural CLD participants, like in this particular distance-delivered program. Two models did reflect positive teacher preparation outcomes in terms of (1) facilitating Latino para-educators to become effective teachers and (2) helping rural pre-service teachers' development of effective, cooperative skills through the use of student teams and partnerships with local school and university faculty.

To illustrate this relatedness, the Latino Teachers Project and the Navajo Nation Teacher Preparation Program addressed preparing para-educators to become teachers in hard-to-staff schools with high CLD student populations (Becket, 1998). Aspects of these projects were (a) highly collaborative in terms of the consortia participants' approaches to 
developing and operating flexible programs, (b) innovative in delivering program knowledge to paraeducators via on-the-job-learning through support teams within local schools and flexible university classes held on site, and (c) effective in establishing strong mentoring relationships among para-educators, faculty members at the home school, and university professors over the course of their program. Becket reported the projects as yielding varying positive outcomes. In the second model, the Indiana University Collaborative Teacher Education Program initiated a model of teacher preparation in rural communities through distance education so teachers could complete requirements for licenses in special education (Knapczyk et al., 2001).

Delivery of courses to three off-campus, rural communities relied upon videoconferencing, the use of team teaching arrangements with on-campus instructors teaming with students on-site, and supervised visits by faculty to assess clinical field experiences. Practica were collaborative in nature with school-based teams of students developing lessons and interventions together. As with the first model, various elements of success were noted, with the most positive outcomes involving student-teambased collaborative networks that continued after the participants' program completion.

\section{Distance-delivered Teacher Preparation Program}

In designing the distance-delivered teacher preparation program, Midwestern State relied upon its longstanding Professional Development School partnership model established in 1999 (Shroyer, Yahnke, Bennett, \& Dunn, 2007) and research regarding culturally responsive teaching previously described. They further relied upon the researchbased strategy of communities of practices for distance learners, particularly in teacher education (Becket, 1998; Knapczyk et al., 2001). These various distance learning teacher preparation models facilitated the selection of specific program components, like on-site student/mentor teacher teams. Assessment of the model's effectiveness occurred continuously throughout its implementation phases (beginning in 2005). Sources of data included faculty surveys, participants' academic progress reports, videotapes of participants' teaching performances, lesson plans and reflections, feedback/evidence forms, student teaching final evaluations, as well as anecdotal field notes.

Setting of the distance-delivered program. All the partner school districts were geographically located in rural, remote regions of the state in cities with Latino populations ranging from a low of $38 \%$ to a high of $44 \%$. These sparsely-populated regions had experienced dramatic increases in CLD populations, mostly of Mexican heritage, in the past ten years primarily because of development in the beef and chicken industries. As such, rural was defined as economic areas dependent upon agriculture, low population density, and locations more than 150 miles from urban centers. Distances from the cities to one another ranged from 60 to 105 miles and up to approximately 333 miles from the Midwestern State campus. Demographics for the three partner school districts ranged from total student populations of 1,730 students to over 7,300 students, low SES populations of $53 \%$ to $71 \%$, and ethnic diversity populations of $61 \%$ to $75 \%$. Latinos (mostly of Mexican descent) were noted as the largest ethnic populations in all three school districts, ranging from $52 \%$ to $69 \%$ of total school populations.

The 15 participants involved in the teacher preparation program functioned as a cohort of preservice teachers, beginning their professional teacher education coursework in fall of 2005 . Fourteen of the participants were female and one participant was male. As previously noted, the participants were primarily place-bound, Mexican Americans who had mostly been employed in school-related occupations prior to their student teaching internships (Fall, 2007).

Implementation of phase \#1 - the general education program. The first phase of the distancedelivered program was structured to allow the nontraditional, CLD teacher candidates to complete the first two years of their coursework (or general education courses) close to home at one of three community colleges. In many cases, the participants already had completed a great deal of coursework prior to joining the program. Unfortunately, their completed courses did not always "match" the established course requirements in Midwestern State's elementary education program or their completed courses were not articulated in alignment with Midwestern State's admission policies.

In order to streamline the transfer process for a community college student interested in completing his/her teaching degree through Midwestern State, the grant leadership realized that alignment in course offerings and changes in program guidelines were needed. Therefore, to gain "buy in" and to ensure institutionalization of necessary long term changes, the grant leaders/researchers established crossinstitutional planning teams made up of faculty across institutions based on content areas. These content teams included the areas of Mathematics, Science, Language Arts, Humanities, Recruitment \& Retention, Social Studies, and Professional 
Education. Each team had representation from K-12 teachers, community college faculty, and faculty from both the College of Education and the College of Arts \& Sciences at Midwestern State. These teams met annually throughout the four years of the grant during Summer Institutes. As such, they provided a particularly critical role in building, delivering, and evaluating the effectiveness of the distance-delivered teacher program throughout all phases of implementation.

In this first phase, however, the teams participated in various tasks of developing and aligning community college and university courses to local and national teacher education standards. One important aspect of this process was the creation of curricula maps for each community college detailing coursework required at each partner community college to fulfill Midwestern State's existing general education degree requirements. To do this, multiple conversations among community college administrators and both College of Education and College of Arts \& Sciences faculty from the university occurred. Unfortunately, during this initial implementation phase, particularly, decisions were made while the partnering institutions were going through the process of developing both personal and professional relationships. As such, time was often limited in terms of the participating faculties' determination of course design and delivery methods for the program and stressful reactions/emotions surfaced at times.

In conjunction with developing curricular maps, the advising of participants as to which general education courses to complete at each of the community colleges occurred during this implementation phase. Because each of the participants had unique life and educational experiences, long range plans of study were individually designed for each teacher candidate (see Figure 1).

\begin{tabular}{|c|c|c|c|c|c|c|}
\hline $\begin{array}{l}\text { Fall '05 } \\
\text { (12 hr) }\end{array}$ & $\begin{array}{l}\text { Spring '06 } \\
\text { (11 hr) }\end{array}$ & $\begin{array}{c}\text { Summer '06 } \\
(9 \mathrm{hr})\end{array}$ & $\begin{array}{l}\text { Fall '06 } \\
(10 \mathrm{hr})\end{array}$ & $\begin{array}{c}\text { Spring '07 } \\
\text { (16 hr) }\end{array}$ & $\begin{array}{c}\text { Summer } \\
\text { '07 }\end{array}$ & $\begin{array}{l}\text { Fall '07 } \\
\text { (16 hr) }\end{array}$ \\
\hline $\begin{array}{l}\text { Elementary } \\
\text { Statistics- } \\
\text { SCCC } \\
\text { (completed) } \\
\text { Anthropology } \\
\text {-BCCC } \\
\text { (completed) } \\
\text { Geology- } \\
\text { GCCC } \\
\text { (completed) } \\
\text { ESL/Dual } \\
\text { Language } \\
\text { Methods } \\
\text { (completed) }\end{array}$ & $\begin{array}{l}\begin{array}{l}\text { Educ. Psychology } \\
\text { (completed) }\end{array} \\
\text { Exceptional Child } \\
\text { (completed) } \\
\text { Tch. Diverse } \\
\text { Learners } \\
\text { (completed) } \\
\text { Math for Elem } \\
\text { Teachers } \\
\text { (completed) }\end{array}$ & $\begin{array}{l}\text { Tchg. as Career } \\
\text { (completed) } \\
\text { Sex \& Health - } \\
\text { SCCC } \\
\text { (completed) } \\
\text { Philosophy- } \\
\text { SCCC } \\
\text { (completed) } \\
\text { ESL Multicultural } \\
\text { Materials } \\
\text { (completed) }\end{array}$ & 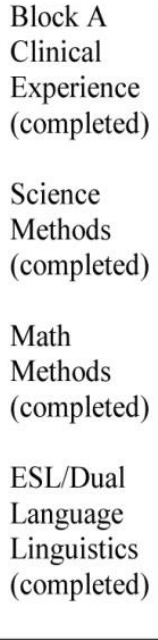 & $\begin{array}{l}\begin{array}{l}\text { Block B } \\
\text { Practicum } \\
\text { (completed) }\end{array} \\
\text { Lang arts } \\
\text { Methods } \\
\text { (completed) } \\
\text { Reading Methods } \\
\text { (completed) } \\
\text { Social Studies } \\
\text { Methods } \\
\text { (completed) } \\
\text { ESL/Dual Lang } \\
\text { Practicum } \\
\text { (completed) }\end{array}$ & & $\begin{array}{l}\text { Block C } \\
\text { Student } \\
\text { Teaching } \\
\text { Internship } \\
\text { (enrolled) }\end{array}$ \\
\hline
\end{tabular}

Figure 1. Example of a participant's long range plan

These plans reflected cultural responsiveness, as the grant leaders/researchers considered a candidate's specific needs, such as his/her previous coursework, work load, and family responsibilities. Additional advising issues arose as the participants engaged in particular general education courses and their needs for academic curricular support emerged. Because several of the pre-service teachers struggled with math and English communications coursework, tutorial support within their plans of study was identified, supported financially by the grant, and then delivered individually. Such tutorial support involved collaborative discussions among the faculty and staff within the College of Arts \& Sciences English and mathematics departments, the community colleges' English and math departments, the community colleges' English as Second Language (ESL) departments, and the comprehensive learning centers (tutorial services) at each of the community colleges. To illustrate, in addition to oneon-one tutoring, enrollment in an Intermediate Grammar in ESL course offered at a community 
college was one of various interventions used to address students' specific English language needs. Other interventions included study groups and technological software. A final element considered in the first implementation phase regarded the planning and delivery of specific, required, upperlevel (300-400 level) general education courses not previously offered by the community colleges. This need was addressed by faculty within the content teams who determined how to collaboratively design and deliver these content courses on-site to the participants. Importantly, as the institutional partners attended to each of these implementation aspects, their focus consistently remained on the participants' strengths and needs - academic, social/emotional, and financial.

Implementation of phase \#2 - the professional teacher education program. In planning for the final two years of their two-plus-two teacher preparation program, content teams and grant leaders considered the delivery processes of professional coursework. Implementation of this phase occurred through an array of teaching formats in a variety of delivery configurations. To explain, some courses were taught solely by Midwestern State faculty, while sitebased instructors (e.g., community college faculty and school district faculty) taught others. In many instances, community college faculty and Midwestern State faculty collaborated to develop and deliver courses jointly. Moreover, course offerings were structured via a variety of both technologymediated and direct instruction modalities. As an example, because the pre-service teachers' technological literacies were predicted to be limited (Menlove \& Lignugaris/Kraft, 2004), one of the first upper-level courses delivered was Instructional Media \& Technology. Content in this course included, among other concepts, how to e-mail and use Blackboard, as well as how to navigate the World Wide Web. It was delivered via video conferencing to multiple sites, online modules, and through faceto-face class sessions on-site. These technology resources (Blackboard and e-mail) then provided communication pathways for other professional education coursework.

To add to the variety of delivery modalities, a few course elements in this phase of the program were also planned and delivered on Midwestern State's campus, and arrangements and accommodations for the pre-service teachers' participation were provided by the grant (lodging \& travel). Although these on-campus course elements were typically brief, the students were required to come to Midwestern State in the fall (2006) at the beginning of their professional block of methods courses (Block A). For this particular block of courses, which included science methods, math methods, and a field experience, the teacher candidates stayed on-campus for approximately two weeks to receive the intensive hands-on training and content instruction needed to effectively teach science and math to students at the elementary level. The remainder of the Block A course activities were conducted off-campus in their home communities by Midwestern State faculty, with site-based faculty (from the community colleges and partner school districts) delivering both academic support and clinical support for participants' field experiences. To maximize the candidates' pedagogical development during the field experience, the grant implementers created school-based teams comprised of the Block A pre-service teachers and their clinical instructors and/or on-site university supervisor.

Through the team-structure, the clinical instructor/university supervisor acted as an interventionist to facilitate discussions of the content and pedagogy previously covered by the on-campus methods faculty to the team participants, as they developed cultural awareness of their students' contextualized factors and implemented the methods in real classroom settings. Given the amount of intervention and "re-teaching" provided during this phase, the planning teams determined that offering content instruction throughout a typical semester period was critical for the participants to effectively process methods coursework. Therefore, the grant implementers only considered face-to-face faculty/student delivery options for the candidates' future methods coursework.

In planning for the supervision and assessment of the Block A clinical practicum, Midwestern State looked to the partner school districts as their administration and faculty had been trained in the College of Education conceptual framework (see Figure 2) and its assessment strategies during Summer Institute workshops. Because the partner schools were previously structured as communities of practice, the arrangement, placement, and supervision of Block A participants was therefore expedited. Each partner school district housed a clinical instructor or master teacher/administrator who acted as a liaison between the school district and the university. Additionally, federal grant funding provided for the salary of an on-site university supervisor who further coordinated collaboration among the partner school districts and the university. Assessment strategies planned for the Block A practicum included (primarily) direct observation feedback, but videotapes of the students' math and science teaching episodes were also utilized. All sources of data were analyzed according to the 
College of Education conceptual framework.

Challenges reflected in the data analyses were then directly addressed in the delivery of the next phase of methods coursework (see Figure 3).

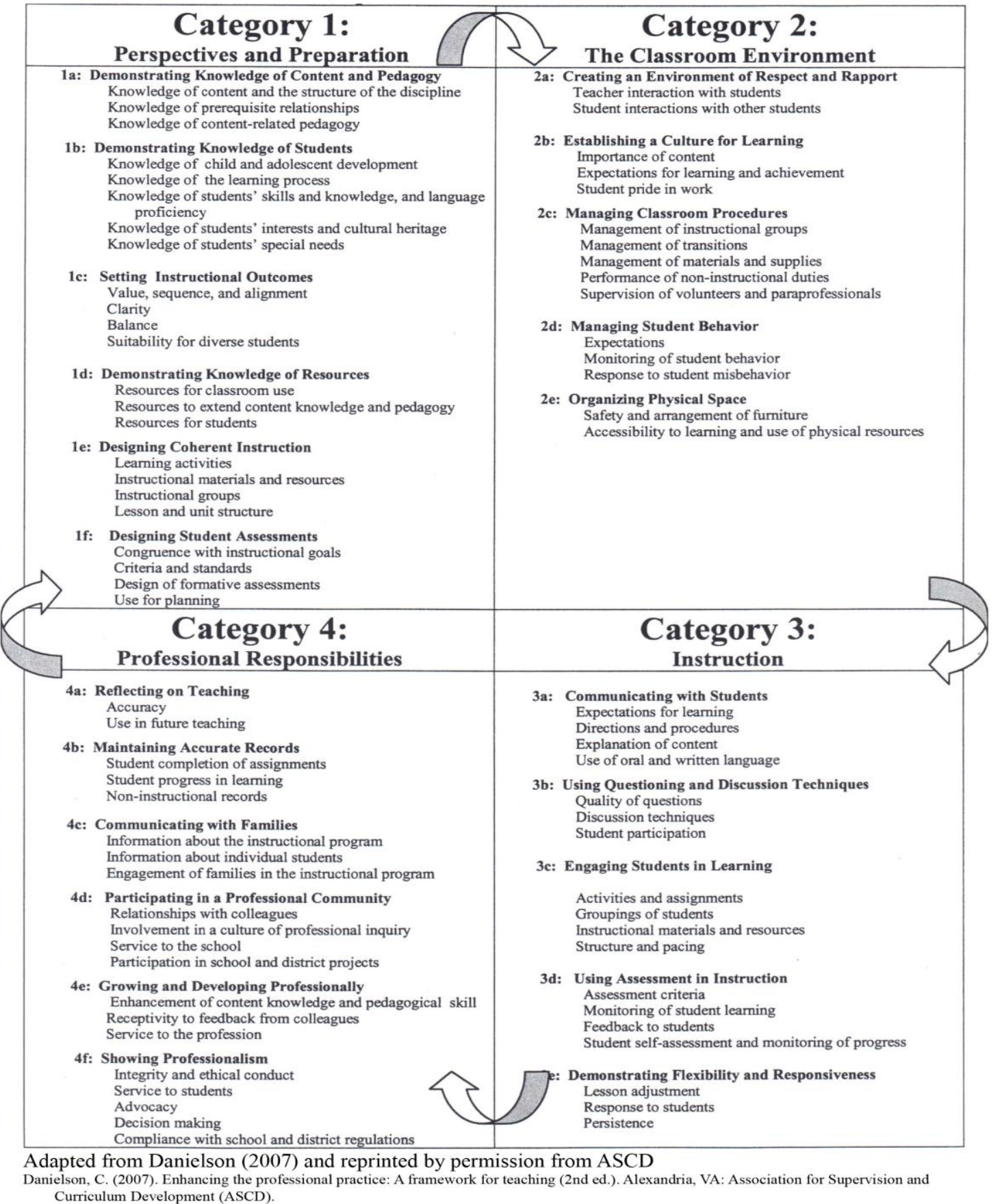

Figure 2. Midwestern State's College of Education Conceptual Framework 


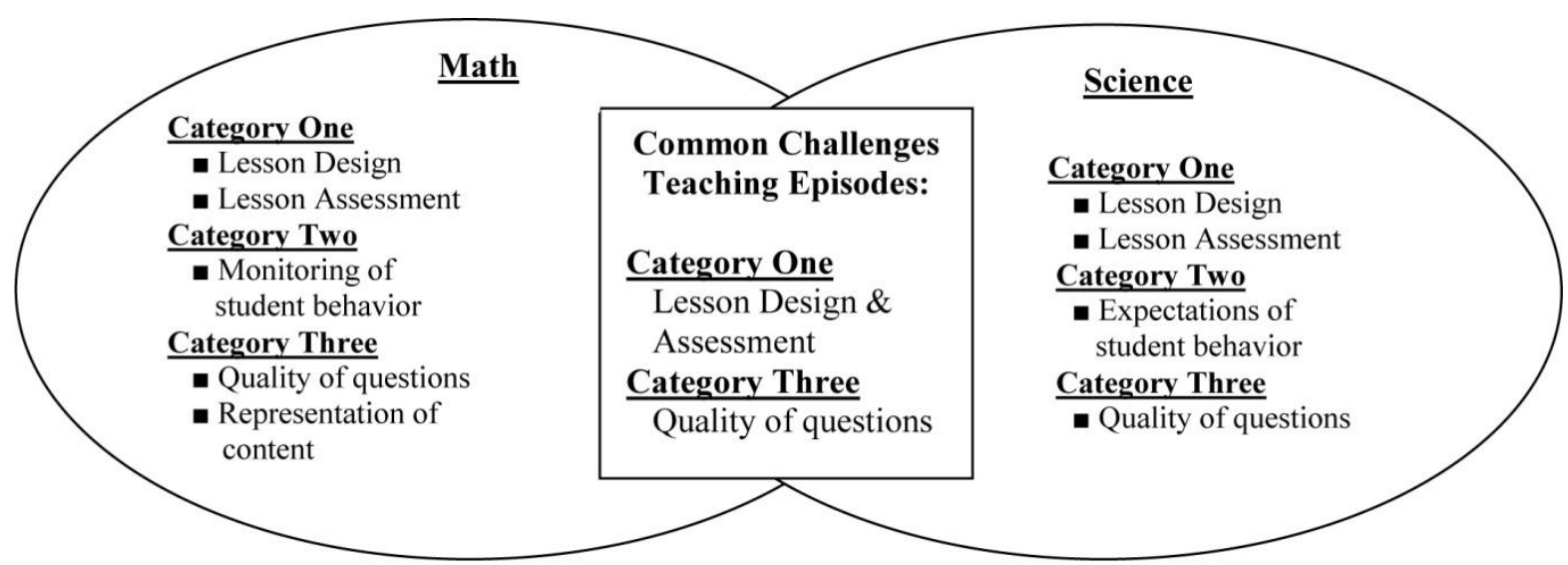

Figure 3. Challenges reflected in participants' Block A teaching performances data analyses

The students' second block of professional courses (Block B) included reading methods, language arts methods, social studies methods, and a field experience. The on-site Midwestern State university supervisor, along with one local community college instructor and one Midwestern State teacher-in-residence, collaboratively taught this block on-site. This instructional design pulled together the rich and varied expertise of the three individuals to best support the students' learning and application of course content. Plans for primarily direct contact delivery, with only some online components (e. g., Blackboard), took into account the grant leaders' increased awareness that nearly half of the participants had limited access to personal computers and/or the Internet. Moreover, direct contact with the faculty expanded the candidates' opportunities to learn effective lesson design and assessment, as individual feedback helped the participants better connect planning and instruction relationships. Clinical field experiences for Block B were planned and implemented similarly to the delivery of the Block A practicum. This time, importantly, assessment data indicated that participants were able to design and implement lessons and assessments more effectively and to ask questions more efficiently.

Implementation of phase \#3 - the professional student teaching internship. For the third and final component of Midwestern State's distance-delivered, teacher preparation program, the teacher candidates were required to complete a 16-week, field-based, internship block. Delivery of the internship coursework occurred via placement at one of the three partnership school districts. Participants were placed in elementary grade levels of kindergarten to fifth grade. Midwestern State faculty and three clinical instructors based at the three partner school districts supervised and assessed on-site clinical practica primarily through direct observations in the classroom, but video-recordings of the candidates' teaching were also collected and utilized as additional evidence of performance.

A total of 4417 written evidences (actual teaching events) were analyzed from all the teacher candidates' student teaching evidence/feedback forms. Seventy percent of all these teaching evidences demonstrated effective teaching characteristics. Specific categorical indicators, like using students' prior learning to build upon skills and knowledge and implementing a variety of learning approaches with numerous resources, were consistently observed in all the participants' teaching behaviors. These written evidences further indicated that the pre-service teachers effectively demonstrated cultural responsiveness by interacting positively with students and by communicating with families in their school districts. Particular evidences related to professionalism showed the participants' cultural competence as they contextualized their students' learning by linking content to their rural CLD backgrounds (e.g., comparing literature of Native American historical cultures to Mexican American historical cultures). Observations from the preservice teachers' video-taped teaching performances supported these written evidences. Moreover, their final student teaching evaluations reflected a mean rating that was above the required "basic" criterion rating based on the conceptual framework assessment 
scale established by the College of Education at Midwestern State.

To summarize the phases of the distancedelivered program model, considerable collaboration among all the partnership institutions was required to operationalize the distance-delivered, teacher preparation program. Consistently, the program used a cohort support system that reflected continuous assessment and subsequent responsiveness to the rural CLD participants' emerging needs. Finally, the program design showed variety in its delivery of teaching modalities, use of mediated technology, and its level of face-to-face student/teacher interactions.

\section{Effectiveness of the distance-delivered}

program. While assessment procedures occurred throughout the implementation phases, particular final assessment strategies were utilized to determine the participants' effectiveness as teachers. To explain, ten Midwestern State and community college faculty and clinical instructors who taught program courses were asked to complete surveys about the distance-delivered teacher preparation program in terms of the pre-service teachers' successfulness as novice teachers. Two open-ended questions were posed: (1) From your experiences with the participants in Block A, Block B, and Student Teaching, comment on what you would consider the overarching strengths and challenges of working with this specific group and (2) Note individual candidates' strength $(s)$ and challenge $(s)$ that stood out to you as they completed your course. Over half of the faculty and supervisors indicated that the participants' teaching strengths were their proficiency in use of the Spanish language (six responses) and their cultural awareness (five responses), and therefore, their abilities to communicate and connect with Latino/as as English language learners and their families. Faculty and clinical instructors/university supervisors also noted that the candidates effectively utilized a variety of teaching approaches (seven responses) and resources and materials (five responses) to help all students learn. In identifying the participants' greatest challenges in the program, over half of the 10 faculty members surveyed identified first the pre-service teachers' language barriers in communicating in Standard English (oral and written), and secondly, their personal issues with driving extended distances to and from class settings and clinical experiences.

\section{Reflections on Implementing the Distance- delivered Program}

Darling-Hammond \& Baratz-Snowden (2005) state that "learning to teach occurs most productively within professional communities" (p. 41) because groups of experienced educators share a set of norms, practices, and collective knowledge across fieldwork with teacher candidates that significantly influence their effective pedagogical skill development. In this teacher education program, a 'community' of learners with shared philosophies and effective teaching practices formed a common vision (frame) for the design, implementation, and continual cultural support of its rural CLD participants. As a result, the program fostered the teacher candidates' development as effective CLD teachers.

As noted, the collaboration among the partnership institutions required that planning for each of the program phases occurred concurrently with actual implementation phases. This situation arose because Project Synergy had initiated its recruitment and selection process for the participants prior to the study, but the actual procedures for delivery of this program were not determined until late in the funding cycle of Project Synergy. Scholarship monies for the participants were limited to a time period, thereby forcing the distance-delivery program to be implemented and the teacher candidates' programs to be completed by the time that the funding for Project Synergy ended. Such issues with financial considerations added to the stress of institutional partners' figuring out how to build and deliver the program responsively.

\section{Communication Challenges for English Language Learner Teacher Candidates}

In reflecting on the needs of the non-traditional, CLD participants involved in the program, the program implementers responded by integrating strong peer cohorts into each phase of the distancedelivered program. Additionally, on-going academic support, consistent advising, and monitoring occurred. However, in spite of this responsiveness to the participants' needs, data collected throughout the program revealed that participants' issues with communication and problems in accessibility to technology (e.g., lack of personal computers) persisted throughout. Furthermore, as native Spanish speakers, the pre-service teachers' primary language was not English, and thus use of the English language, both orally and in writing, presented obstacles. Problems were most evident in such areas as writing lesson plans.

While the distance-delivered program reflected modifications in response to the participants' specific academic and social needs, few changes to the existing College of Education teacher preparation model at Midwestern State occurred. As such, the writing-intensive curricula posed problems for many 
of the pre-service teachers. The need for extensive, targeted support and development of participants' academic writing was one lesson learned in relation to implementation of the upper-level curricula.

\section{Barriers Imposed by Distance}

In terms of implementing the distance-delivered program, barriers imposed by distances proved challenging for the institutional partners. The extreme distances among the school districts, the community colleges, and Midwestern State frequently hindered effective communications and slowed the collaborative processes. Driving was inevitable; even the participants expressed concerns regarding the financial demands made on them due to travel. Distances lessened the participants' direct contact with faculty and advisors. Even although some Project Synergy staff and partnership staff were located in the rural areas, the pre-service teachers' opportunities for direct contact were limited due to distant locations imposed by their jobs and family situations, as well as the distances among the partner sites.

Distance also impacted the effectiveness of key content delivery. The program implementers considered that the pre-service teachers' conceptual learning of planning and preparation pedagogy (e.g., lesson plan design and implementation) was affected by the distance delivery component of professional coursework, or more specifically, the Block A courses. As described, the teacher candidates' instruction for Block A consisted of a hybrid "oncampus-intensive-two-weeks course" and an "offcampus-online-mediated course," with clinical instructors/university supervisor offering on-site academic support. This hybrid method of delivery negatively affected the participants' learning and thus limited their initial effectiveness in demonstrating pedagogical understanding.

\section{Implications for Teacher Education}

In this study, the researchers described the design, implementation, and evaluation of a distancedelivered teacher preparation program to rural, CLD participants, as they trained to be effective teachers. Findings indicated that collaborative endeavors were critical to the program's development, and that the successfulness of such a collaborative partnership has significant implications for the field of teacher education. The ultimate success story for the partner institutions, however, was the graduation of 13 of the 15 participants with bachelor degrees in educationeffective, bilingual teachers who could return to their rural school districts and increase the number of CLD teachers in the region. At the close of the study, the remaining two participants were still in progress of completing their final coursework and requirements and had plans to graduate the following year.

Because Midwestern State and its partners acknowledged various implementation issues in the discussion of its program, specific implications for future research endeavors can be drawn.

\section{Implication \#1}

Distance-delivered models of teacher preparation can produce teachers who display effective teaching characteristics. However, this model demonstrated how delivery concerns may have impacted the teacher candidates' development of effective lesson design; thus, each component within the model for preparing the teacher candidates' pedagogical understanding must be evaluated critically. Future distance-delivered program endeavors need to consider elements of (a) time required by teacher candidates to process methods coursework in distance learning settings, (b) modification of core tasks to reflect communication issues likely to appear for distance learners, particularly English language learners, and (c) the positive impact that intertwining the core tasks of teaching - cultural competence and experience, reflection, and study — within the clinical practicum has upon the cultural experiences of rural and diverse student populations.

\section{Implication \#2}

Utilizing community resources via "grow your own" pre-service teacher training programs can be a viable means for meeting the needs of CLD students in rural areas. In this model, the CLD teacher candidates were effective at responding to their pupils with a level of comfort or familiarity - aided by commonalities of ethnicity, language, community, and heritage. The participants showed cultural responsiveness by knowing how to connect the home and rural community experiences of their pupils, and because the candidates were Spanish speakers, they additionally offered language resources to both the school and the community. Their awareness of rural living provided them added experiential knowledge to facilitate their students' learning.

\section{Conclusions}

The challenge of providing for the effective teaching of CLD students, particularly in rural, remote areas of the US, continues. Universities, colleges, and local school districts together must meet this challenge. While Flores, Keehn, and Pérez 
(2002) assert that the grow-your-own approach is a feasible, asset-based alternative to rural districts' desperate attempt to recruit teachers of color, the description of this teacher preparation program showed how extensive the collaborative nature of partnerships needs to be in order to successfully implement such a program. Findings from this study reflected that funding for all components of the program is essential. Implementers across the partnerships also acknowledged that even though they planned program components with nontraditional CLD participants' backgrounds in mind, barriers, such as the participants' lack of academic

\section{References}

Achinstein, B., Ogawa, R. T., Sexton, D., \& Freitas, C. (2010). Retaining teachers of color: A pressing problem and a potential strategy for "hard-to-staff" schools. Review of Educational Research, 80(1), 71-107.

Becket, D. R. (1998). Increasing the number of Latino and Navajo teachers in hard-to-staff schools. Journal of Teacher Education, 49(3), 196-206.

Bernal, C., \& Aragon, L. (2004). Critical factors affecting the success of paraprofessionals in the first two years of career ladder projects in Colorado. Remedial and Special Education, 25(4), 205-213.

Bransford, J., Darling-Hammond, L, \& LePage, P. (2005). Introduction. In L. Darling-Hammond \& J. Bransdord (Eds.). Preparing teachers for a changing world: What teachers should learn and be able to do (pp. 1-39). San Francisco: JosseyBass.

Cochran-Smith, M. (2004). Walking the road: Race, diversity, and social justice in teacher education. New York: Teachers College Press.

Darling-Hammond, L., \& Baratz-Snowden, J. (Eds.). (2005). A good teacher in every classroom. San Francisco: Jossey-Bass.

Darling-Hammond, L., Hammerness, K., Grossman, P., Rust, F., \& Shulman, L. (2005). The design of teacher education programs. In L. Darling-

Hammond \& J. Bransford (Eds.), Preparing teachers for a changing world: What teachers should learn and be able to do (pp. 390-441). San Francisco: Jossey-Bass.

Flores, B. B., Keehn, S., \& Pérez, B. (2002). Critical need for bilingual education teachers: The potentiality of normalistas and paraprofessionals. Bilingual Research Journal, 26(3), 501-520.

Flores, B. B., Clark, E. R., Claeys, L., \& Villareal, A. language proficiency, still presented significant obstacles. Despite these noted challenges, all teacher educators have an obligation to design and sustain collegiate environments conducive to recruiting and supporting CLD teachers into the existing teaching force. The need for rural CLD teachers is and will continue to be significant (Heimbecker, Medina, Peterson, Redsteer, \& Prater, 2002). As reflected in this study, CLD teacher candidates offered significant cultural responsivity to rural, diverse populations of students - an effective teaching characteristic that is desperately needed for today's children.

(2007). Academy for teacher excellence: Recruiting, preparing, and retaining Latino teachers through learning communities. Teacher Education Quarterly, 34(4), 53-69.

Gay, G. (2002). Preparing for culturally responsive teaching. Journal of Teacher Education, 53(2), 106-116.

Gay, G., Dingus, J. E., \& Jackson, C. W. (2003). Recruiting teachers of color. Denver, CO: Education Commission of the States.

Guiterrez, R. (2006). Beyond essentialism: The complexity of language in teaching mathematics to Latino/a students. Unpublished doctoral dissertation, Kansas State University at Manhattan, KS.

Heimbecker, C., Medina, C., Peterson, P., Redsteer, D., \& Prater, G. (2002) Reaching American Indian special/elementary educators through a partnership with a Navajo Nation school district. Remedial \& Special Education, 23(6), 372-378.

Jung, L. A., Galyon-Keramidas, C., Collins, B., \& Ludlow, B. (2006). Distance education strategies to support practica in rural settings. Rural Special Education Quarterly, 25(2), 18-24.

Knapczyk, D., Chapman, C., Rodes, P., \& Chung, H. (2001). Teacher preparation in rural communities through distance education. Teacher Education and Special Education, 24(4), 402-407.

Ladson-Billings, G. (1995). Toward a theory of culturally relevant pedagogy. American Educational Research Journal, 32(3), 465-491.

Menlove, R., \& Lignugaris/Kraft, B. (2004). Preparing rural distance education pre-service special education teachers to succeed. Rural Special Education Quarterly, 23(2), 18-26.

Moll, L. C., Armanti, C., Neff, D., \& Gonzalez, N. (1992). Funds of knowledge for teaching: Using a qualitative approach to connect homes and 
classrooms. Theory into Practice, 31(2), 132141.

Noel, A., \& Sable, J. (2010). Public elementary and secondary school student enrollment and staff from the common core of data: School year 2007-08 (NCES 2010-309). National Center for Education Statistics, Institute of Education Sciences, U.S. Department of Education. Washington, DC.

Olson, S. J., \& Werhan, C. (2005). Teacher preparation via online learning: A growing alternative for many. Action in Teacher Education, 27(3), 76-84.

Portes, P. (2008). A cultural approach to establishing equity and closing the educational achievement gap. Penn GSE Perspectives on Urban Education, 5(2). Retrieved October 12, 2011, from http://urbanedjournal.org/archive/Vol.\%205\%20I ss. $\% 202 \% 20$ Order\%20in

Reynolds, E., Treahy, D., Chao, C., \& Barab, S. (2001). The Internet learning forum: Developing a community prototype of teachers of the $21^{\text {st }}$ century. Computers in the schools, 17(3/4), 107125.

Rueda, R., Monzó, L. D., \& Higareda, I. (2004). Appropriating the sociocultural resources of Latino paraeducators for effective instruction with Latino students. Urban Education, 39(1), 52-90.

Skylar, A. A., Higgins, K., Boone, R., Jones, P., Pierce, T., Gelfer, J. (2005). Distance education: An exploration of alternative methods and types of instructional media in teacher education. Journal of Special Education, 20(3), 25-33.

Shroyer, G., Yahnke, S., Bennett, A., \& Dunn, C. (2007). Simultaneous renewal through professional development school partnerships. The Journal of Educational Research, 100(4), 195-206.

US Census Bureau. (2008). Selected social characteristics in the United States: 2006. Retrieved October 12, 2011, from http://factfinder.census.gov/servlet/ADPTable?_ bm=y\&-geo_id=01000US\&ds_name=ACS_2006_EST_G00_

Valenciana, C., Weisman, E.M., Flores, S.Y. (2006). Voices and perspectives of Latina paraeducators: The journey toward teacher certification. The Urban Review, 38(2), 81-99.

Villegas, A. M., \& Lucas, T. (2007). The culturally responsive teacher. Educational Leadership, 64(6), 28-33.

Vygotsky, L. S. (1986). Thought and language. Cambridge, MA: Institute of Technology Press.

Gayla Lohfink is an Assistant Professor in the Department of Curriculum \& Instruction at Wichita State University.

Amanda Morales is an Assistant Professor and Graduate Student Advisor in the Department of Curriculum \& Instruction at Kansas State University.

Gail Shroyer is a Professor and Chair of the Department of Curriculum \& Instruction at Kansas State University. She is Co-Director of Professional Development Schools.

Sally Yahnke is an Associate Professor and Co-Director of Professional Schools in the Department of Curriculum \& Instruction at Kansas State University.

Cecilia Hernandez is a Project Coordinator in the Office of Diversity at Kansas State University. 